Original article

\title{
Eleştirel Düşünme Eğilimlerinin Okuduğunu Anlama, Öğrenci, Aile ve Ev Ortamı Değişkenleri Bağlamında İncelenmesi
}

\section{Determination of Critical Thinking Disposition in the Context of Reading Comprehension, Student, Family and Home Environment Variable}

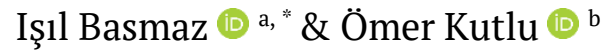 \\ a Measurement and Evaulation Specialist Robert College, Istanbul, Turkey \\ ${ }^{b}$ Department of Educational Measurement and Evaluation, Faculty of Educational Sciences, Ankara University, Ankara, Turkey
}

\begin{abstract}
Özet
Bu araştırmada, ortaokul 7. sınıf öğrencilerinin eleştirel düşünme eğilimleri ile okuduğunu anlama, öğrenci, aile ve ev ortamı değişkenleri arasındaki ilişkinin belirlenmesi amaçlanmıştır. Araştırma yordayıcı korelasyon türündedir. Araştırmanın çalışma grubu, 2016-2017 eğitim-öğretim yılında Çorum ilinde ortaokul 7. sınıfta öğrenim gören toplam 508 öğrenciden oluşmaktadır. Veri toplama aracı olarak Kaliforniya Zihinsel Güdülenme Ölçeği, Öğrenci Bilgi Anketi, Okuduğunu Anlama Testi ve Okuduğunu Anlama Testine Ait Dereceli Puanlama Anahtarı kullanılmıştır. Araştırma verilerinin çözümlenmesinde hiyerarşik çoklu regresyon analizi kullanılmıştır. Araştırmada öğrencilerin eleştirel düşünme eğilimlerini yordayan faktörler belirlenmiştir. Elde edilen sonuçlar doğrultusunda öğrencilerin okuduğunu anlama becerilerinin eleştirel düşünme eğilimlerini önemli derecede yordadığı görülmektedir. Ayrıca, sinema ya da tiyatroya gitme sıklığı ve evdeki kitap sayısı değişkenleri de öğrencilerin eleştirel düşünme eğilimlerini yordamaktadır.
\end{abstract}

Anahtar Kelimeler: Eleştirel düşünme eğilimi, okuduğunu anlama becerisi, üst düzey düşünme, hiyerarşik çoklu regresyon, ortaokul

\begin{abstract}
In this study, It is aimed to determine the relationship between critical thinking disposition and reading comprehension, students, family and home environment of 7th grade students. This study is designed as a predictive correlation study as it means to identify the predictive variables for critical thinking disposition. The study group consists of 508 seventh grade students who were educated in 2016-2017 education term in Corum city. California Measure of Mental Motivation Scale, students questionnaire, reading comprehension test and its rubric were used as data collection tools. Hierarchical multiple regression analysis was used in order to determine the factors that predict the critical thinking disposition of students in the study. The results advocate that students' reading comprehension skills play an important role in their critical thinking disposition. Besides, going to cinema or theatre and the number of the books at home are predictors of critical thinking disposition.
\end{abstract}

Keywords: Critical thinking disposition, reading comprehension skill, higher order thinking, hierarchical multiple regression, secondary school

Received:07 October 2021 * Accepted:15 December $2021 \quad * \quad$ DOI: https://doi.org/10.29329/dmer.2021.409.2

\footnotetext{
* Corresponding author:

Işıl Basmaz, Measurement and Evaulation Specialist Robert College, Istanbul, Turkey. Email: isilbasmaz@gmail.com
} 


\section{GíRIŞ}

Yirminci yüzyılda olduğu gibi yirmi birinci yüzyılda da, teknolojinin ve iletişim olanaklarının gelişimini sürdürmesiyle bilimsel bilginin değeri artmaya devam etmiştir. Toplumsal yaşamdaki katı kurallar ve uygulamalar, tek boyutlu insan yaklaşımı ve değerlendirmeleri, bilimsel anlayışın yaygınlaştığı ve nitelikli insan sermayesinin önem kazandığı bu yüzyılın özelliklerine ters düşmektedir. $\mathrm{Bu}$ nedenle günümüzde yeni eğitim anlayışlarına ve uygulamalarına gereksinim duyulmaktadır (Şentürk, 2008). Toplumların temel güç kaynağı olan geçerli bilginin üretilmesi ve kullanılması eğitim sistemine yeni sorumluluklar yüklemektedir. Kültürel değerlerin yeni nesillere aktarılmasında küresel dünyanın gerektirdiği bilgi, beceri, tutum ve değerlere sahip bireyler yetiştirebilmek eğitim sisteminin en önemli sorumlulukları arasında yer almaktadır (Çalık ve Sezgin, 2005).

Öğrencilerin düşünme becerilerini geliştirmek öğrenme-öğretme sürecinin temelini oluşturmaktadır. Düşünme; bireylerin gözlemleri ve deneyimleriyle edindikleri bilgileri kavramsallaştırmaları, çözümleyebilmeleri, değerlendirmeleri ve farklı durumlara uyarlamaları amacıyla gerçekleştirilen zihinsel bir etkinliktir. Düşünmeyi öğrenmek ise anlamlı öğrenme gerçekleştiğinde meydana gelmektedir. Düşünme becerisiyle birlikte sonucunda parça parça edinilen bilgiler bir bütün haline getirilerek mevcut bilgilerin ötesine gidilebilmekte ya da mevcut bilgilerden yola çıkarak başka bilgilere ulaşılabilmektedir (Şaban, 2002). İnsan, doğası gereği doğal ve toplumsal olaylar hakkında düşünmekte, davranışlarını etkileyen olayları keşfetmeye çalıştığında eleştirel düşünme süreci başlamaktadır (Brookfield, 2012; Forshaw, 2012). Bu durumda eleştirel düşünme bireylere, akıl ve mantık çerçevesinde çıkarımlar yapmayı, nesnel biçimde doğru ve yanlışı ayırt etmeyi sağlamaktadır (Küçükali ve Akbaş, 2015).

Eleştirel düşünme için; araştırma yapma, mantıksal çıkarımlarda bulunma, sorgulama, sorular sorup yanttlar bulabilme ve organize olabilme (düzenleme) becerileri gerekmektedir (Cohen, 1993; Eales-Reynolds vd, 2013; Rirozzi ve diğerleri, 2008). Eleştirel düşünme, farklı kaynaklardan alınan bilgilerin anlamlandırılmasında, karmaşık düşüncelerin yeniden inşa edilmesinde etkili olmaktadır. Eleştirel düşünme, stratejik bir düşünme olup farklı bakış açılarıyla olayları çözümleyebilmeyi ve ayrıntıları anlayabilmeyi gerektirir. Böyle düşünen bireyler, durumların güçlü ve zayıf yönlerini belirleyerek sorunları anlamakta ve farklı durumlarda bu sorunların nasıl değerlendirileceğini bilmektedir (Moon, 2007).

Dünyada özgür düşünceye ve evrensel hukuka dayalı yeni bir ekonomik sistem kurulmaktadır. Eskiden olduğu gibi doğal kaynaklar, tarım ya da jeopolitik konum bir ülkeyi gelişmiş ülke düzeyine getirmeye yetmemektedir. Yeni ekonominin temel girdisi bilgi ve beceridir. Bilgiye özgürce ulaşan, yurttaşlarına bu bilgiyi uygulama ve geliştirme becerisi kazandıran toplumlar yeni ekonominin zenginleri olmaktadır (Şirin, 2015). Bu nedenle bireylerin öğrencilik yaşamından çalışma yaşamına kadar her süreçte belirli becerileri kazanmış olması beklenmektedir. Bu beceriler arasında eleştirel 
düşünme ve okuduğunu anlama önemli yere sahiptir. Bu özelliklere sahip bireylere sahip olmak isteyen toplumların ise zihinsel becerilerin geliştirilmesini amaç edinen eğitim sistemlerine gereksinimleri vardir (MEB, 2011).

Gözlem yapma, karar verme, çözümleme ve mantıklı düşünme eleştirel düşünme becerisinin odak noktasını oluşturmaktadır. Bu beceriyi kazanan bireyler herhangi bir durumla ilgili kilit noktayı belirleyebilme yeteneğini geliştirerek, ayrıntıların önemini belirlemekte ve amaca odaklanmaktadırlar (Cottrell, 2005). Eleştirel düşünme; etkin olma, bağımsız olma, yeni fikirlere karşı istekli olma, fikirleri destekleyen nedenleri göz önünde tutma ve fikirlerin düzenlenmesine önem verme gibi birçok farkl1 beceriyi içermektedir (Cüceloğlu, 2001). Kutlu ve diğerleri (2017) öğrencilerin eleştirel düşünme sürecinde; olgular, olaylar, durumlar vb. hakkında belli ölçütlerden yararlanarak karar verme, karşılaştırma yapma belli ilkelerden yararlanarak mantıklı yordama yapma becerilerini göstermeleri gerektiğinden söz etmektedir.

Eleştirel düşünme becerisinin kazanılması için, öğrencinin etkin rol alması ve yaşamı nasıl anlamlandıracağını bilmesi gerekmektedir. Bu süreçte açık görüşlü olmak eleştirel düşünme için kritik bir öneme sahip olduğundan hem öğretmenlerin hem de öğrencilerin açık görüşlü olması ve olaylara farklı bakış açılarıyla bakabilmesi gerekmektedir (Black, 2005; Crews-Anderson, 2007; Hooks, 2010). Öğrenciler, eleştirel düşünme becerisi sayesinde durumları keşfetmeyi öğrenerek bunu bir beyin alışkanlığına dönüştürebilmektedir. Bu nedenle bu becerinin gelişmesi için öğretmenler öğrencilere uygun öğrenme ortamları oluşturmalıdır (Leader ve Middleton, 2004). Eleştirel düşünme becerisini geliştirmek için; sınıf içinde tartışma, karşıt görüşü çürütme, yanıttan probleme gitme, amaçlar belirleme ve bu amaçlara ulaştıracak yolları düşünme, düşüncelerdeki tutarsız olan yanları belirleme ve bu tutarsızlıkların üstesinden gelecek çözüm yolları önerme gibi becerilerin kullanılmasını gerektiren etkinlikler tasarlanmalıdır (Doğan, 2013).

Eleştirel düşünme eğilimlerinin kazandırılması amacıyla öğrencilerin düşüncelerini paylaşabilecekleri ve birbirlerini değerlendirebilecekleri öğrenme ortamları hazırlanmalı, düşünme süreçleri izlenerek nitelikli soru sorabilme ve sorgulayabilme durumları üzerinde durulmalıdır. Toplumsal olaylara karşı eğilimleri ve ön yargıları saptamak için farklı görüşleri ön planda tutan eserlerin incelenmesi, eleştirel düşünme becerilerinin kazandırılmasında etkilidir (Seferoğlu ve Akbıyık, 2006). Eleştirel düşünme öğrencilere özgürlük yaratmakta, akıl yürüterek olaylar arasındaki bağlantıları keşfetmelerini sağlamakta ve bu sayede güdüyü arttırarak başarılı olmaya katkıda bulunmaktadır (Brookhart, 2010).

Uluslararası Matematik ve Fen Eğilimleri Araştırması (Trends in International Mathematics and Science Study -TIMSS), Uluslararası Öğrenci Değerlendirme Programı (Programme for International Student Assessment -PISA) ve Uluslararası Okuma Becerilerinde Gelişim Projesi (The Project of International Reading Language Skills -PIRLS) gibi çalışmalar öğrenci performansını ve bu performansı 
etkileyen faktörleri araştırmaktadır. Bu çalışmalarda, öğrenci performansının arka planını oluşturan özellikler hakkında veri toplamak amacıyla öğrenci anketleri kullanılmaktadır. $\mathrm{Bu}$ araştırmaların bulguları, aile özelliklerinin ve ev olanaklarının, öğrencilerin bilgi ve becerileri üzerinde etkili olduğunu göstermektedir (MEB, 2003; 2010; 2015). Bu nedenle, öğrencilerin eleştirel düşünme becerilerinin istenilen düzeye ulaşabilmesi için olası etkenlerin göz önünde bulundurulması önem taşımaktadır.

Bilgiyi edilgen olarak almaya alışmış öğrencilerin, bilgi yoğunluğu karşısında eleştirel seçimler yapmaları, akademik çalışmaları için ölçüt ve stratejiler oluşturmaları ve karşılaştıkları karmaşık sorunları çözmeleri zor olmaktadır. Bunların gerçekleştirilebilmesi için öğrencilere, bilgileri edilgen biçimde sorgulamadan almaları değil; bilgileri işlerken ve ayıklarken eleştirel olmalarının önemi öğretilmelidir (Şahinel, 2002). Eleştirel düşünme becerisine sahip olan bireyler internet üzerinden bilgi toplama, büyük bir veriyi taramayı, taranan bilgiyi süzme ve güvenirliğini değerlendirme gibi becerilere sahip olduğundan eleştirel düşünme, okuma becerileri bakımından her zamankinden daha önemli duruma gelmektedir (MEB, 2015).

Öğrencilerin eleştirel düşünme becerilerinin gelişmesi için dikkate alınması gereken önemli bir öge de, öğrencilerin eleştirel okuma becerileridir. Öğrencinin bir metne eleştirel gözle bakabilmesi için öncelikle okuma ve anlama becerilerine sahip olması gerekmektedir. Bu nedenle, eleştirel düşünmenin gerçekleşebilmesi öğrencilerin okuma ve okuduğunu anlama becerilerinin gelişmiş olmasına bağlıdır (Gelder, 2005). Okuma ve okuduğunu anlama becerisi; öğrenmeyi, tartışmayı, araştırmayı, yorumlamayı ve eleştirel düşünmeyi sağlayan süreç içerisinde yer almaktadır. Öğrencilerin, okumayı alışkanlık haline getirerek okuduklarını değerlendirebilmeleri ve eleştirel bir bakış açıcısıyla yorumlayabilmeleri, bu becerilerin gelişmesi sürecinde önemli rol oynamaktadır (MEB, 2006; 2009).

Okuduğunu anlama, insanın dünyasını genişletmesinde ve kişiliğini biçimlendirmesinde önemli bir etkendir. İki ayrı kavram gibi görünen, insanları gerçek anlamda özgür kılan okuma ve anlama arasında aslında neden-sonuç ilişkisi bulunmaktadır. İnsanlar anlamak için okumakta, okuduklarını da anlamak istemektedir (Demirel, 2002). Okuma, insanların yalnızca bilgi edinmek, aklına takılan soruların yanıtlarını bulmak ya da başkalarının yaşantı ve deneyimlerini paylaşmak için kullandığı bir araç olmamaktadır. Okuma aynı zamanda insanın düşünce gücünü geliştiren önemli bir araçtır. Okuduğu her yazıyı anlamaya çabalayan insan bu yolla anlama, sezme ve tahmin etme gücünü geliştirmektedir. Metinde anlatılanların ya da öne sürülen düşüncelerin geçerliğini değerlendirmekte yazarla benzer düşünme yapısına sahip olup olmadığını belirlemektedir. Bütün bunlar, öğrencilerde eleştirel bir tutum oluşturmaktadır. Bu yönden okuduğunu anlama becerisi, eleştirel düşünceyi diri tutan ve onu besleyen bir tür kaynaktır (Özdemir, 2011).

Anlama, doğumdan hemen sonra; konuşma, yaklaşık bir yaş civarında; yazma ve okuma ise okul eğitimiyle birlikte başlamaktadır. Bu dört becerinin ortak noktası bireyin düşünme gücünün gelişmesiyle ilgilidir. Dilin geliştirilebilmesi için bu dört kanalın geliştirilmesi gerekmektedir. Bu nedenle, dil 
öğretimine resmi olarak başlanan ilköğretim basamağı çok önemlidir (Kutlu, 1999). Bloom'a (1995) göre, bu beceri, öğrenciliğin ilk yıllarında kazanılmakta ve öğrencinin öğrenmesini eğitim-öğretim yaşamı boyunca etkilemektedir. $\mathrm{Bu}$ nedenle okuduğunu anlama becerisi kazanamamış bireylerin, eleştirel düşünmeyi de kapsayan üst düzey zihinsel süreçlerde başarılı olmaları olası değildir.

Kurnaz-Adıbatmaz ve Kutlu'ya (2020) göre, küçük yaştaki öğrenciler genellikle çok az bilgiyle sonuca ulaşmaya çalışılar. Bu nedenle onların ayrıntıları dikkate alarak eleştirel biçimde değerlendirebilmeleri desteklenmelidir. Öğrenciler, okuma becerilerini eleştirel niteliğe dönüştürdüğünde, okuduklarından sonuçlar çıkarıp değerlendirme yapabilecek düzeye gelir. Böylece her öğrenci çok yönlü bir yapıya sahip okuma metinlerinden çıkarımlar yapabilir. Eleştirel okuma becerisine sahip öğrenciler, yazarın metin içinde aktardığı bilgilerin gerçek yaşamdaki boyutlarının karşılığını arayarak bulmaya çabalar. Öğrencilerin metin içinde olan bilgilerin gerçekliğini ve güvenirliğini sorgulaması gerekir. Eleştirel okuyucu, metni sorgulayarak karşıllaştırma yapabilir ve çıkarımlarda bulunabilir. Ayrıca bu beceri, öğrencilerin metni yorumlamasının dışında metni tanımasını, metne yönelik soruları yanıtlamasını ve yeni düşünceler geliştirebilmesini gerektiren zihinsel becerileri kapsamaktadır (Karadüz, 2010). Eleştirel düşünen okur, okuduğu yazıyı değişik boyutlarda çözümlemelere tabi tutarak yeniden üretir ve anlamlandırır. Eleştirel okumanın, üst düzey becerileri kapsaması için metnin anlaşılması, yorumlanması ve amacının belirlenmesi gerekmektedir (Afflerbach, Cho ve Kim, 2015). Bu süreçlerin gerçekleşmesi için öğrencilerin okuma öncesi, sırası ve sonrasındaki durumlara eleştirel gözle bakabilmesi gerekmektedir (Jones, 1985).

Öğrenme-öğretme sürecinde eleştirel düşünme, bilginin oluşumunda ve anlamlandırılmasında ayrıca öğrencilerin farklı kaynaklardaki bilgileri çözümleyerek kendi düşüncelerini oluşturmasında önemli rol oynamaktadır. Alanyazın incelendiğinde, bu becerinin öneminden de kaynaklanarak çeşitli araştırmalar yapıldığı görülmektedir (Kanik, 2010; Kürüm, 2002; Polat, 2014; Ralston ve Bays, 2015; Shim ve Walczak, 2012). Kutlu ve Altıntaş (2021) kısa yanıtlı, çoktan seçmeli, boşluk tamamlamalı vb. ölçme yaklaşımlarının alt düzey öğrenmelerin ölçülmesinde etkili olduğunu; problem çözme ve eleştirel düşünme gibi üst düzey düşünme becerilerinin ölçülmesinde yeterince etkili olamadığını vurgulamaktadır. Bu nedenle öğrencilerin problem çözme, eleştirel düşünme ve yaratıcılık gibi bilişsel yapıların gelişiminde içsel (intrapersonal) ve kişilerararsı (interpersonal) özelliklerin de sınıf içi öğrenme süreçlerine dahil edilmesi gerektiğine dikkat çekmektedir.

Eleştirel düşünme, araştırmalarda her açıdan ele alınmış öğrenci, öğretmen ve öğretim etkinlikleri değişkenleri başta olmak üzere çeşitli değişkenler üzerinde çalışılmıştır. Ancak bu araştırmalarda eleştirel düşünme ile okuduğunu anlama arasındaki ilişkileri ele alan çalışmalara yeteri kadar rastlanamamıştır. Bu araştırma, bu iki becerinin birbiriyle ilişkisini ve aynı zamanda öğrenci, aile ve ev ortamı özellikleriyle de ilişkisini ortaya koyarak alanyazına katkıda bulunmayı hedeflemiştir. 
Çalışmanın giriş bölümünde de belirtildiği gibi eleştirel düşünme becerisinin eğitim-öğretim sürecindeki önemi nedeniyle araştırmalar yapılmakta ve bu becerinin öğrencilere kazandırılması için önemi vurgulanmaktadır. Öğrencilerin eleştirel düşünmeleri üzerinde etkili olan faktörlerin her zaman araştırılması gerektiği ve eğitimde gelişmeyi sağlayacak bir konu olduğu düşünülmektedir. Bu nedenle eleştirel düşünme becerisinin geliştirilmesi, bu becerinin gelişime etki eden faktörlerin belirlenmesiyle yakından ilgilidir. Öğrenci başarısının gelişiminde önemli rol oynayan üst düzey düşünme süreçlerinden eleştirel düşünme becerilerini geliştirecek yolların bulunması ve okul uygulamaları için önerilmesi bir gerekliliktir.

Özellikle Türkiye'de eleştirel düşünme becerisinin okuduğunu anlama, öğrenci, aile ve ev ortamı değişkenleriyle olan ilişkisini ortaya koyan az sayıda araştırma bulunmaktadır. Bu araştırma, bu gereksinime katkı sağlamak amacıyla yapılmıştır. Araştırmaya, eleştirel düşünme ve okuduğunu anlama ile ilişkili olduğu düşünülen değişkenlerden öğrenci, aile ve ev ortamı da dahil edilmiştir. Bu nedenle araştırma sonuçlarının öğrenciler, öğretmenler, okul yönetimi, aileler ve eğitim paydaşları için yol gösterici olacağı düşünülmektedir.

\section{Araştırmanın Amacı ve Önemi}

$\mathrm{Bu}$ araştırmanın amacı, ortaokul 7. sınıf öğrencilerinin eleştirel düşünme eğilimleri ile okuduğunu anlama, öğrenci, aile ve ev ortamı değişkenleri arasındaki ilişkiyi ortaya koymaktır. Araştırmanın amacı çerçevesinde kapsamında aşağıdaki bulunan sorulara yanıt aranmıştır:

Araştırmanın yürütüldüğü öğrenci grubunun eleştirel düşünme eğilimlerini;

a. öğrencilerin okuduğunu anlama testinden aldığı puan,

b. öğrenci özelliklerinden

- cinsiyet

- öğrenciye ait kitap sayıs1

- okul dışında günde ortalama kitap okumaya ayrılan zaman

- sinema ve tiyatroya gitme siklı̆̆

c. aile özelliklerinden

- annenin ve babanın eğitim durumu

- annenin ve babanın çalışma durumu

d. ev ortamı özelliklerinden

- evde sahip olunan olanaklar (bilgisayar, internet, kitaplık, çalışma masası, çalışma odası)

- evdeki kitap sayısı değişkenlerinden hangileri yordamaktadır? 


\section{YÖNTEM}

\section{Araştırma Modeli}

$\mathrm{Bu}$ araştırmada, ortaokul 7. sınıf öğrencilerinin eleştirel düşünme eğilimlerinin okuduğunu anlama, öğrenci, aile ve ev ortamı değişkenleri açısından incelenmesi amaçlanmıştır. Çalışmada öğrencilerin eleştirel düşünme eğilimlerini yordayan faktörlerin belirlenmesi amaçlandığı için bu araştırma yordayıcı korelasyon türündedir. Korelasyonel araştırmalarda iki ya da daha fazla sayıda değişkenin arasında olan ilişkiler incelenmektedir. Korelasyon türü araştırmalarda değişkenlerin birlikte değişim gösterip göstermedikleri, eğer birlikte değişim oluyorsa bu değişimin nasıl olduğu belirlenmektedir (Fraenkel ve Wallen, 2006; Karasar, 2012). Yordayıcı korelasyon çalışmalarında değişkenlerin arasındaki ilişkiler incelenmekte ve değişkenlerin bilinen bir değerine göre diğer değişken yordanmaktadır (Büyüköztürk ve diğerleri, 2013).

\section{Çalışma Grubu}

Araştırmanın çalışma grubu, 2016-2017 eğitim-öğretim yılı güz döneminde Çorum ilindeki devlet okullarında öğrenim gören ortaokul 7. sınıf öğrencilerinden oluşmaktadır. Amaca uygun olarak altı okul seçilmiş ve verilerin elde edilmesi için uygulama 508 öğrenci üzerinde yürütülmüştür. Uygulama yapılan okullar belirlenirken, okulların 2015-2016 eğitim-öğretim yılında gerçekleştirilen Temel Eğitimden Ortaöğretime Geçiş (TEOG) sınavında aldıkları başarı puan ortalamaları göz önünde bulundurulmuştur. Okulların başarı sırası dikkate alınmış ve okullar üst, orta ve alt olarak gruplandırılmıştır.

Araştırmanın temel amacı doğrultusunda öğrencilerin akademik başarıları, ailenin ve öğrencilerin özellikleri açısından çeşitlilik olması amaçlanmıştır. Bu nedenle çalışma grubu seçkisiz olmayan örnekleme yöntemlerinden amaçsal örnekleme kullanılarak oluşturulmuştur (Fraenkel ve Wallen, 2006). Uygulama okulları ve öğrenci sayıları Tablo 1'de verilmiştir.

Tablo 1. Çalışma grubunda yer alan okullar ve öğrenci sayıları

\begin{tabular}{llll}
\hline Gruplar & Okullar & N & Toplam \\
\hline \multirow{2}{*}{ Üst Grup } & Salim Akaydın Ortaokulu & 101 & \multirow{2}{*}{179} \\
& 23 Nisan Ortaokulu & 78 & \\
\hline \multirow{2}{*}{ Orta Grup } & Dr. Sadık Ahmet Ortaokulu & 91 & \multirow{2}{*}{170} \\
& Karşıyaka Ortaokulu & 79 & \multirow{2}{*}{158} \\
\hline \multirow{2}{*}{ Alt Grup } & Yatılı İlköğretim Bölge Okulu & 52 & \\
& Cumhuriyet Ortaokulu & 106 & $\mathbf{5 0 8}$ \\
\hline \multirow{2}{*}{ Toplam } & & $\mathbf{5 0 8}$ & \\
\hline
\end{tabular}

Araştırmaya katılan 508 öğrencinin üst, orta ve alt gruplara dağılımı birbirine oldukça yakındır. Öğrencilerin 270’i $(\% 53,15) \mathrm{k1z}, 238$ 'i $(\% 46,85)$ ise erkektir. 


\section{Veriler ve Toplanması}

Bu çalışmada Kaliforniya Zihinsel Güdülenme Ölçeği, Öğrenci Bilgi Anketi ve Okuduğunu Anlama Testi olmak üzere üç farklı veri toplama aracı kullanılmıştır. Ayrıca Okuduğunu Anlama Testinde bulunan maddeleri puanlamak için de dereceli puanlama anahtarları da geliştirilmiştir.

Kaliforniya Zihinsel Güdülenme Ölçeği (KZGÖ), Giancarlo ve Facione (2001) tarafindan öğrencilerin eleştirel düşünme eğilimlerinin ölçülmesi için geliştirilmiştir. Ölçek, 6. sınıftan 12. sınıfa kadar öğrenim gören öğrencilere uygulanmaktadır. Bu ölçeğin amacı, öğrencilerin akıl yürütme becerilerini kullanmalarını gerektiren zihinsel etkinliklerle hangi düzeyde uğraştığı ve bilişsel süreçlerde ne derecede güdülenmiş olduğunu belirlemektir. Ölçek, Özdemir (2006) tarafindan Türkçe’ye uyarlanmıştır. Araştırmada, ölçeğin hedef dil (Türkçe) ve özgün dil (İngilizce) formlarının dil eşdeğerliğinin sağlanıp sağlanmadığının anlaşılabilmesi için formlardan alınan puanlar karşılaştırılmış ve manidar bir farklılık bulunmamıştır. Ölçeğin hedef dil ve özgün dil arasındaki dilsel eşdeğerliği sağladığı belirlenmiştir. KZGÖ'nün Cronbach Alfa güvenirlik katsayıları, ölçeğin alt boyutlarında .60 ile .66 arasında değişirken ölçeğin tamamında .78 olarak bulunmuştur. Bu araştırmanın çalışma grubundan elde edilen Cronbach Alfa güvenirlik katsayıları ise, ölçeğin alt boyutlarında .63 ile .68 arasında değişmiş, ölçeğin tamamında ise .88 olarak bulunmuştur.

Öğrenci bilgi anketinde, öğrencilerin eleştirel düşünme eğilimlerine ve okuduğunu anlama becerilerine etki edeceği düşünülen öğrenci, aile ve ev ortamı özelliklerinin belirlenmesine yönelik maddeler yer almaktadır. Öğrenci, aile ve ev ortamı değişkenlerine ilişkin veri toplamak amacıyla PISA, TIMMS ve PIRLS sınavlarında kullanılan anket maddelerinden öğrencilerin eleştirel düşünme eğilimlerini etkileyeceği düşünülen on dört madde seçilmiştir. Anket maddelerinin geçerliğini sağlamak amacıyla anket psikometrik, dil ve anlatım özellikleri açısından uygunluğunun incelenmesi için iki Türk dili, iki ölçme ve değerlendirme uzmanın görüşüne sunulmuştur. Uzmanların görüşleri dikkate alınarak maddeler gözden geçirilmiş ve anketin asıl formu oluşturulmuştur.

Okuduğunu Anlama Testi, Kutlu ve Erman Aslanoğlu (2008) tarafindan geliştirilmiştir ve sekiz açık uçlu maddeden oluşmaktadır. Araştırmacılar metinde yer alan maddeleri PIRLS'de (2003) yer alan kavrama süreçleri içindeki bilişsel düzeylere göre hazırlanmışlardır. Metnin ve maddelerin uygulamasının üzerinden zaman geçtiği için, okuma testi için yeniden uzman görüşü alınmış ve ön deneme uygulaması yapılmıştır. Test, bilişsel düzeylerin neyi temsil ettiğini anlatan bir yönerge ile dört ölçme ve değerlendirme uzmanının görüşüne sunulmuş ve gerekli düzenlemelerden sonra deneme uygulaması yapılmıştır. Okuduğunu anlama testinin deneme uygulaması araştırmacının görev yapmakta olduğu okulda toplam 69 öğrenciye uygulanmıştır. Okuduğunu anlama testi yanıtlandıktan sonra öğrencilerden, maddelerin sınıf ve yaş düzeylerine uygunluk ile anlaşılırlığı açısından görüşleri alınmıştır. Okuduğunu anlama testinden elde edilen puanların güvenirliği için puanlayıcı güvenirliği incelenmiştir. Her bir maddeyi üç ayrı puanlayıcı dereceli puanlama anahtarı kullanarak birbirlerinden 
bağımsız olarak puanlanmıştır. Puanlar arası ilişki Pearson Momentler Çarpımı Korelasyon Katsayısı ile hesaplanmış ve puanlayıcı güvenirlikleri .92 ile .94 arasında yüksek değerler olarak bulunmuştur.

Okuduğunu Anlama Testi'nde yer alan maddelerin puanlanması için dereceli puanlama anahtarları hazırlanmış ve her bir maddeye verilen yanıtlar için tanıma kodları oluşturulmuştur. Tanıma kodlarına göre; 10: En doğru yanıtı; 13, 15 ve 18: Uzak doğru yanıtları; 50: Boş yanıtı; 60: Yanlış yanıtı ve 70: Ilişskisiz yanıtı ifade etmektedir. Dereceli puanlama anahtarlarının yanıt tanımlarının ve derecelemelerinin uygunlukları açısından değerlendirilmesi amacıyla DPA, dört ölçme ve değerlendirme uzmanına gönderilmiştir. Gelen dönütler doğrultusunda gerekli düzeltmeler yapılmıştır.

\section{Verilerin Çözümlenmesi}

Ortaokul 7. sınıf öğrencilerinin eleştirel düşünme eğilimlerini yordayan değişkenlerin neler olduğunun belirlenmesinde çoklu doğrusal regresyon analizi yaklaşımlarından hiyerarşik çoklu regresyon analizi kullanılmıştır. Bu analizde, yordayıcı değişkenler araştırmacı tarafından belirlenen sıraya göre analize alınmakta, her yordayıcı değişken ya da yordayıcı değişken seti kendi giriş noktasında denkleme ne kadar katkı sağladığına göre değerlendirilmektedir (Field, 2013; Tabachnick ve Fidell, 2001).

Araştırmada yordanan (bağımlı) değişken, Kaliforniya Zihinsel Güdülenme Ölçeği'nden alınan puanlardır. Yordayıcı (bağımsız) değişkenler ise Öğrenci Bilgi Anketinden ve Okuduğunu Anlama Testinden elde edilen verilerdir.

Ankette yer alan değişkenler; öğrencilerin cinsiyeti, anne ve baba eğitim durumu, anne ve baba çalışma durumu, evde sahip olunan olanaklar, öğrencinin kendine ait kitap sayısı, evdeki kitap sayısı, okul dışında günde ortalama kitap okumaya ayrılan zaman ve sinema ya da tiyatroya gitme sıklı̆̆ıdır. Araştırmada bulunan süreksiz değişkenlerin çözümlemeye dahil edilebilmesi için yapay değişkenler kodlanmıştır. Çünkü doğrusal regresyonun bir yöntemi olan hiyerarşik regresyonun yapılabilmesi için değişkenleri ilişkin ölçümlerin sürekli olması gerekmektedir. Bu çalışma ile etkisi araştırılan bazı değişkenler süreksiz değişkenlerdir. Bu değişkenlerin analize dahil edilebilmesi için kukla (dummy) değişken olarak 0-1 şeklinde kodlanması gerekmektedir.

Araştırma sorularının çözümlenmesi için öncelikle çoklu doğrusal regresyon analizi varsayımlarının (kayıp ve uç değerlerin incelenmesi, bağımlı ve bağımsız değişkenler arasında doğrusal ilişkinin olması, değişkenlerin çok değişkenli normal dağılım göstermesi, değişenler arasında çoklu bağlantıllğın bulunmaması, hata terimlerinin bağımsız olması) karşılanıp karşılanmadığı sırasıyla incelenmiştir (Field, 2013; Pallant, 2015; Tabachnick ve Fidell, 2001). Verilerin, çözümlemenin varsayımlarını karşıladığı görülmüştür. 


\section{BULGULAR ve YORUMLAR}

Araştırma sorusunun yanıtını bulmak için hiyerarşik yapının oluşturulmasında ilk bloğa okuduğunu anlama testi puanlarl, ikinci bloğa öğrenci özellikleri, üçüncü bloğa aile özellikleri ve dördüncü bloğa ev ortamı özellikleri değişkenleri alınmıştır. Çözümlemede dört blok içinde yer alan değişkenlerin öğrencilerin eleştirel düşünme eğilimlerini ne derecede yordadıkları incelenmiş, sonuçlar Tablo 2'de verilmiştir.

Tablo 2. Eleştirel düşünme eğilimi regresyon analizi sonuçları

\begin{tabular}{|c|c|c|c|c|c|c|c|c|c|c|c|c|}
\hline Model & Değişken & B & $\mathbf{S H}_{\mathbf{B}}$ & $\mathbf{R}$ & $\mathbf{R}^{2}$ & $\Delta \mathbf{R}^{2}$ & $\mathbf{F}$ & $\mathbf{B}$ & $\mathbf{t}$ & $\mathbf{p}$ & $\begin{array}{l}\text { İkili } \\
\text { r }\end{array}$ & $\begin{array}{l}\text { Kismi } \\
\mathbf{r}\end{array}$ \\
\hline \multirow{2}{*}{1} & Sabit & 56.49 & 0.74 & 0.77 & 0.59 & 0.59 & 738.04 & & 76.33 & 0.00 & & \\
\hline & OkuduğunuAnlamaPuan & 0.43 & 0.02 & & & & & 0.77 & 27.17 & 0.00 & 0.77 & 0.77 \\
\hline \multirow{3}{*}{2} & Sabit & 61.99 & 3.65 & 0.79 & 0.62 & 0.61 & 53.39 & & 17.01 & 0.00 & & \\
\hline & OkuduğunuAnlamaPuan & 0.38 & 0.02 & & & & & 0.69 & 20.95 & 0.00 & 0.77 & 0.69 \\
\hline & Sinema/tiyatro_d2 & 3.69 & 1.50 & & & & & 0.08 & 2.47 & 0.01 & 0.10 & 0.11 \\
\hline \multirow{3}{*}{3} & Sabit & 60.61 & 5.78 & 0.79 & 0.63 & 0.61 & 28.79 & & 10.48 & 0.00 & & \\
\hline & OkuduğunuAnlamaPuan & 0.38 & 0.02 & & & & & 0.69 & 19.31 & 0.00 & 0.77 & 0.66 \\
\hline & Sinema/tiyatro_d5 & 3.95 & 1.56 & & & & & 0.08 & 2.54 & 0.01 & 0.10 & 0.12 \\
\hline \multirow{7}{*}{4} & Sabit & 60.96 & 5.80 & 0.80 & 0.64 & 0.61 & 22.08 & & 10.51 & 0.00 & & \\
\hline & OkuduğunuAnlamaPuan & 3.38 & 0.02 & & & & & 0.69 & 19.34 & 0.00 & 0.77 & 0.67 \\
\hline & Sinema/tiyatro_d2 & 3.55 & 1.57 & & & & & 0.07 & 2.25 & 0.03 & 0.10 & 0.10 \\
\hline & Sinema/tiyatro_d5 & 2.08 & 1.02 & & & & & 0.08 & 2.04 & 0.04 & 0.17 & 0.09 \\
\hline & EvdekiKitapSayıs1_d1 & -4.76 & 2.04 & & & & & $\begin{array}{l}- \\
0.24\end{array}$ & -2.33 & 0.02 & $\begin{array}{l}- \\
0.29\end{array}$ & -0.11 \\
\hline & EvdekiKitapSay1s1_d2 & -4.96 & 2.00 & & & & & $\begin{array}{l}- \\
0.22\end{array}$ & -2.48 & 0.01 & $\begin{array}{l}- \\
0.03\end{array}$ & -0.11 \\
\hline & EvdekiKitapSayıs1_d3 & -4.53 & 1.88 & & & & & $\overline{-}-18$ & -2.14 & 0.02 & 0.00 & -0.11 \\
\hline
\end{tabular}

Tablo 2'de görüldüğü gibi, hiyerarşik çoklu regresyon analizi dört bloktan oluşmaktadır. Eleştirel düşünme eğilimlerini önemli derecede etkilediği düşünülen okuduğunu anlama testi puanları çözümlemeye birinci sırada, öğrenci özellikleri değişkenlerinin etkisinin kontrol edilmesi amaciyla bu değişkenler ikinci sırada dahil edilmiştir. Aile özellikleri değişkenleri ise öğrencilerin evde sahip oldukları olanakları etkileyeceği düşünüldüğü için üçüncü sırada, ev olanakları değişkenleri dördüncü sırada çözümlemeye dahil edilmiştir.

Öğrencilerin eleştirel düşünme eğilimlerinin yordanmasına ilişkin çözümleme sonuçlarına göre, birinci blokta çözümlemeye dahil edilen okuduğunu anlama testi puanları, öğrencilerin eleştirel düşünme eğilimlerinin manidar bir yordayıcısı olarak bulunmuştur. Öğrencilerin okuduğunu anlama 
testinden aldıkları puanlar, KZGÖ’nden alınan puanlara ilişkin varyansın \%59’unu açıkladığı görülmektedir $(\mathrm{t}=27.17, \mathrm{p}<.01)$.

İkinci blokta, çözümlemeye dahil edilen sinema ve tiyatroya haftada bir gitme sıklı̆g 1 (sinematiyatrogitme_d2) değişkeninin öğrencilerin eleştirel düşünme eğilimlerini manidar olarak yordadığı bulunmuştur. Okuduğunu anlama testinden alınan puanlara ek olarak öğrenci özelliklerine ilişkin değişkenler çözümlemeye dahil edildiğinde, öğrencilerin sinema ve tiyatroya haftada bir gitme sıklığı (sinematiyatrogitme_d2) değişkeninin çözümlemeye getirdiği katk1 \%1,6'dır (t=2.47, p<.01). Bu değişkenle birlikte eleştirel düşünme eğilimlerine ilişkin açıklanan varyans \%61 olmaktadır. Öğrenci özellikleri içinde yer alan cinsiyet, öğrenciye ait kitap sayısı ve okul dışında günde ortalama kitap okumaya ayrılan zaman değişkenleri regresyon modeline girmemiştir.

Üçüncü blokta aile özellikleri içinde yer alan değişkenler (anne eğitim durumu, baba eğitim durumu, anne çalışma durumu, baba çalışma durumu) çözümlemeye eklenmiştir. Çözümlemenin üçüncü bloğunda aile özellikleri içinde yer alan faktörlerden hiç biri manidar olarak bulunmamıştır. Regresyon analizinde, önceki bloklarda manidar yordayıcı olarak belirlenen okuduğunu anlama puanı ve sinema ve tiyatroya gitme sıklığı değişkenleri yine manidar yordayıcılardır. Modelin üçüncü blogunda, öğrencilerin eleştirel düşünme eğilimlerine ilişkin açıklanan varyans \%61'dir. Aile özellikleri içinde yer alan değişkenler regresyon modeline girmemiştir.

Dördüncü blokta ev ortamı özellikleri içinde yer alan değişkenler (bilgisayar ya da tablet, internet bağlantısı, kendine ait kitaplık, kendine ait çalışma masası, kendine ait çalışma odası, evdeki kitap sayıs1) çözümlemeye dahil edilmiştir. Bu blokta evdeki kitap sayısı değişkenleri regresyon denklemine manidar katkı yapmaktadır. Evdeki kitap sayısı değişkenlerinden 1-50 arası ( $\mathrm{t}=-2.33, \mathrm{p}<.01), 51-100$ $\operatorname{aras1}(\mathrm{t}=-2.48, \mathrm{p}<.01)$ ve 101-200 ( $\mathrm{t}=-2.14, \mathrm{p}<.01)$ aras1 kitap sayısına sahip olma (evdekikitapsay1s1_d1, evdekikitapsayısı_d2, evdekikitapsayısı_d3) değişkeninin eleştirel düşünme eğilimlerinin manidar bir yordayıcısı olarak bulunmuştur. Bu değişkenle birlikte eleştirel düşünme eğilimlerine ilişkin açıklanan varyans \%61 olmaktadır. Ev ortamı özellikleri içinde yer alan bilgisayar ya da tablet, internet bağlantısı, kendine ait kitaplık, kendine ait çalışma masası, kendine ait çalışma odası değişkenleri regresyon modeline girmemiştir. Bir diğer anlatımla, bu eleştirel düşünme eğiliminin manidar birer yordayıcısı olarak belirlenmemişlerdir.

Yordayıcı değişkenler ile yordanan değişken arasındaki ikili ve kısmi korelasyonlar incelendiğinde sonuçlar şöyledir:

- Okuduğunu anlama puanı ile eleştirel düşünme eğilimlerinin ilişkisi pozitif yönde ve yüksek düzeyde $(r=0.77)$ iken, diğer değişkenler kontrol altına alındığında iki değişkenin ilişkisi pozitif yönde ve orta düzeydedir $(r=0.67)$. 
- Öğrencinin sinema ve tiyatroya hafta bir gitme s1klı̆g1 (sinematiyatrogitme_d2) ile eleştirel düşünme eğilimlerinin ilişkisi pozitif yönde ve düşük düzeyde $(r=0.10)$ iken, diğer değişkenler kontrol altına alındığında iki değişkenin ilişkisi yine pozitif yönde ve düşük düzeydedir $(\mathrm{r}=0.10)$.

- Öğrencinin sinema ve tiyatroya üç ayda 1-2 kez gitme sıklı̆̆1 (sinematiyatrogitme_d5) ile eleştirel düşünme eğilimlerinin ilişkisi pozitif yönde ve düşük düzeyde $(r=0.17)$ iken, diğer değişkenler kontrol altına alındığında iki değişkenin ilişkisi yine pozitif yönde ve düşük düzeydedir $(r=0.09)$.

- Öğrencinin evinde 1-50 arası kitap sayısı (evdekikitapsayısı_d1) ile eleştirel düşünme eğilimlerinin ilişkisi negatif yönde ve düşük düzeyde $(r=-0.27)$ iken, diğer değişkenler kontrol altına alındığında iki değişkenin ilişkisi yine negatif yönde ve düşük düzeydedir ( $r=-0.11)$.

• Öğrencinin evinde 51-100 arası kitap sayısı (evdekikitapsayısı_d2) ile eleştirel düşünme eğilimlerinin ilişkisi negatif yönde ve düşük düzeyde $(r=-0.03)$ iken, diğer değişkenler kontrol altına alındığında iki değişkenin ilişkisi yine negatif yönde ve düşük düzeydedir (r=-0.11).

- Öğrencinin evinde 101-200 arası kitap sayısı (evdekikitapsayısı_d3) ile eleştirel düşünme eğilimlerinin ilişkisi negatif yönde ve düşük düzeyde $(r=-0.00)$ iken diğer değişkenler kontrol altına alındığında iki değişkenin ilişkisi yine negatif yönde ve düşük düzeydedir $(r=-0.11)$.

Regresyon analizi bulgularına göre, okuduğunu anlama testinden alınan puan, sinemaya ve tiyatroya gitme sıklığı ve evdeki kitap sayısı değişkenleri eleştirel düşünme eğilimlerindeki toplam varyansın \%61,2'sini açıklamaktadır. Hiyerarşik çoklu regresyon analizinde, yordayıcı değişkenlerin yordanan değişkene ilişkin görece öneminin yorumlanmasında standardize edilmiş regresyon katsayıları (ß-Beta) değerleri incelenmiştir. Yordayıcı değişkenlerin $\beta$ değerleri incelendiğinde okuduğunu anlama testinden alınan puanlar, öğrencilerin eleştirel düşünme eğilimlerini en fazla açıklayan en önemli yordayıc1 $(\beta=.69)$ olarak bulunmuştur.

\section{SONUÇLAR ve TARTIȘMA}

Eleştirel düşünme eğiliminin yordanan; okuduğunu anlama, öğrenci özellikleri, ev olanakları değişkenlerinin yordayıcı olduğu regresyon modeline ilişkin elde edilen bulgulara dayalı olarak, eleştirel düşünme eğilimlerinin en iyi yordayıcılarının, okuduğunu anlama testi puanı, öğrencilerin sinema ya da tiyatroya gitme sıklığı, öğrencilerin evlerinde bulunan kitap sayısı olduğu sonucuna ulaşılmıştır. Hiyerarşik çoklu regresyon analizi sonucunda bu üç değişkenin eleştirel düşünme eğilimlerindeki toplam varyansın \%61'ini açıkladığı sonucuna varılmıştır.

$\mathrm{Bu}$ araştırmada okuduğunu anlama testinden alınan puanlar öğrencilerin eleştirel düşünme eğilimlerinin en önemli yordayıcısı olarak bulunmuştur. Daha önce yapılan çalışmalarda bu iki beceri arasındaki ilişki orta ya da yüksek düzeyde bulunmuştur (Aloqaili, 2011; Karimi ve Veisi, 2016; Marzban ve Barati, 2016; Yousefi ve Mohammadi, 2016). Koç’un (2007) araştırmasında; geleneksel 
yönteme göre aktif öğrenme yönteminin okuduğunu anlama ve eleştirel düşünme becerileri üzerinde daha etkili olduğu bulunmuştur. Diğer bir araştırmada ise Waldmann Modelinin 8. sinıfta öğrenim gören öğrencilerin eleştirel düşünme ve okuduğunu anlama becerileri üzerinde istatistiksel olarak manidar olduğu belirtilmiştir (Balta ve Demirel, 2012). Ghabanchi ve Behrooznia (2014) tarafindan yapılan araştırmada beyin firtınası stratejilerinin eleştirel düşünme ve okuduğunu anlama becerilerini önemli derecede etkilediği bulunmuştur.

PISA okuma becerileri alanında öğrencilerin okuma yeterliklerini altı düzeyde tanımlamaktadır. 6. düzey öğrenciden metni ya da metnin ayrıntılarını tam olarak anlama, birçok ölçütü ve görüşü göz önünde bulundurarak ve metnin ötesinde bir anlayış sergileyerek alışagelmiş konuların dışındaki metinler üzerinde eleştirel bir değerlendirme yapabilme. gibi becerileri içermektedir. 6. düzeyde başarılı olan Türk öğrencilerin oranı PISA 2009'da \%1,8; PISA 2012'de \%4,1; PISA 2015'te \%0,6; PISA 2018'de ise \%0,2'dir (MEB, 2015; 2016; 2019). Türkiye, okuma becerilerinde gelişim göstermeye başlamasına rağmen 6. düzeyde yer alan öğrenci sayısı oldukça azdır. Eleştirel düşünme ve okuduğunu anlama becerisini geliştirmek için bu becerileri birbirinden bağımsız olarak düşünülmemesi gerekmektedir.

Araştırmada öğrencilerin sinema ve tiyatroya gitme değişkeninin eleştirel düşünme eğilimlerini manidar biçimde yordadığı da bulunmuştur. Bu bulgu alanyazında yapılan araştırmalardan farklılık göstermektedir. Demir ve Aybek'in (2014) lise öğrencilerinin eleştirel düşünme eğilimlerinin çeşitli değişkenlere göre incelediği araştırmada öğrencilerin bilimsel, sportif ve kültürel etkinliklere katılmasının eleştirel düşünme becerileri üzerinde etkili olmadığı görülmüştür. Hemşirelik öğrencileri üzerinde yürütülen bir araştırmada öğrencilerin sosyal ve kültürel etkinliklere katılmasının eleştirel düşünme düzeylerinde etkili olmadığı bulunmuştur (Öztürk, 2006). Kaloç (2005) çalışmasında, lise öğrencilerinin eleştirel düşünme becerilerini etkileyen etmenleri araştırmış ve belgesel izleme değişkenini ele almıştır. Belgesel izleyen ve izlemeyen öğrencilerin "Eleştirel Düşünme Becerileri Ölçeği”nden aldıkları puanların ortalamaları arasında manidar bir fark bulmamıştır.

Araştırmada öğrencilerin eleştirel düşünme eğilimlerini, evdeki kitap sayısı değişkeninin manidar biçimde yordadığı, öğrencinin kendisine ait kitap sayısının ise manidar bir yordayıcı olmadığı görülmüştür. Bu araştırmada evdeki kitap sayısı ailedeki kitap okumanın bir göstergesi, kendine ait kitap sayısı ise öğrencilerin kitap okumasının bir göstergesi olarak düşünülmüştür. Kutlu ve diğerlerinin (2011) yaptığı araştırmada ilköğretim 5. sınıf öğrencilerinin okuduğunu anlamada başarılı olup olmadıkları durumların kestirilmesinde etkili olan değişkenler incelenmiştir. Araştırmanın sonucunda öğrencilerin evlerinde bulunan kitap sayısı ve kendilerine ait kitap sayısının artmasına bağlı olarak okuduğunu anlamada başarılı olma olasılıklarını arttırdıkları bulunmuştur. Akar ve Kara'nın (2016) araştırmasında ise ilkokul 4. sınıf öğrencilerinin eleştirel düşünme becerileri bazı değişkenler açısından 
değerlendirilmiştir. Buna göre, öğrencilerin eleştirel düşünme becerilerini yordamada en önemli değişkenin ders başarısı olduğu, ikinci değişkenin ise okunan kitap sayısı olduğu sonucuna varılmıştır.

Öğrencilerin günde kitap okumaya ayırdıkları ortalama zaman değişkeninin, eleştirel düşünme eğilimlerini manidar bir şekilde yordamadığı görülmektedir. Çalışmanın bu bulgusu Susar Kırmızı ve diğerleri (2014) tarafından yapılan araştırma bulgularıyla çelişmektedir. Susar Kırmızı ve diğerlerinin (2014) yaptığı araştırmada, sınıf öğretmeni adaylarının eleştirel düşünme eğilimlerinin toplam puanlarıyla okuma alışkanlığına ilişkin tutumları arasında düşük düzeyde, pozitif yönde ve manidar bir ilişki bulunmuştur. Bulgulardaki bu farklılığın nedeninin çalışma kapsamında uygulanan ankette fazla madde olmasından kaynaklanabileceği düşünülmektedir. Kitap okuma alışkanlığının eleştirel düşünme üzerindeki etkisi mutlaka göz önünde bulundurulmalıdır. Kitap okumaya zaman ayırmak kadar anlayarak okumak ve okuduğunu yorumlayabilmek, günlük yaşamla ilişkilendirebilmek ve değerlendirebilmek çok önemlidir. Alanyazında eleştirel düşünme becerisini etkileyen faktörler arasında kitap okuma alışkanlığının olmadığı çalışmalar bulunmasına rağmen eleştirel düşünme eğiliminin kitap okuma alışkanlığını etkilediğini gösteren araştırmalar bulunmaktadır (Asi Karakaş ve diğerleri, 2016; Greene ve Serro, 2015).

Araştırmada cinsiyet değişkeninin eleştirel düşünme eğilimlerini manidar biçimde yordamadığ 1 bulunmuştur. Bu bulgu diğer araştırmalarla paralellik göstermiştir (Bağc1 ve Şahbaz, 2012; Piji Küçük ve Uzun, 2013).

Anne babanın eğitim ve çalışma durumu değişkenlerinin, öğrencilerin eleştirel düşünme eğilimlerinin manidar bir yordayıcısı olmadığı görülmektedir. Gök ve Erdoğan'ın (2011) araştırmasında da öğrencilerin eleştirel düşünme eğilimleriyle annenin ve babanın eğitim durumu arasında ilişkinin manidar olmadığı bulunmuştur. Demir ve Aybek (2014), lise öğrencilerinin eleştirel düşünme eğilimlerini çeşitli değişkenler açısından incelemiştir. Araştırmanın bulgularına göre annenin ve babanın eğitim düzeylerine ve ailelerin genel yapısına göre eleştirel düşünme eğilimleri puanının manidar biçimde farklılaşmadığı sonucuna ulaşılmıştır.

Öğrencilerin ev olanakları değişkenlerinin, eleştirel düşünme eğilimlerini manidar biçimde yordamadığı görülmektedir. Araştırmada ev olanakları içerisinde bilgisayar ya da tablete sahip olma, internet erişimi, çalışma odası, çalışma masası ve kitaplık yer almaktadır. Bu değişkenlerin hiçbiri öğrencilerin eleştirel düşünme eğilimlerini manidar biçimde yordamamaktadır. Araştırmanın değişkenleri arasında yer alan ev olanakları ailenin sosyoekonomik durumunun göstergelerinden biridir. PISA 2012 raporunda ailenin sosyoekonomik durumu, ev olanaklarından evde bilgi ve iletişim teknolojilerine erişim düzeyi, evdeki eğitimsel kaynaklar ve refah düzeyi ile tanımlanmıştır. $\mathrm{Bu}$ değişkenler içerisinde ailenin sosyoekonomik durumunu en iyi açıklayan değişken ev olanakları, sonrasında evdeki bilgi ve iletişim teknolojilerine erişim düzeyidir (MEB, 2015). Araştırmada ev olanaklarının içerisine bilgisayar ya da tablet ve internet bağlantısı öğrencilerin eleştirel düşünme 
eğilimlerini manidar biçimde yordamadığı görülmektedir. Ayrıca öğrencinin evde kişisel alanı olup olmadığının göstergesi olan kendine ait çalışma odasının ve çalışma masasının olup olmaması değişkeni de eleştirel düşünme eğilimin manidar bir yordayıcısı değildir.

Araştırmanın bulgularına dayalı olarak bazı takım öneriler geliştirilmiştir. Bunlardan ilki eleştirel düşünme eğiliminin geliştirilmesi için okuma ve okuduğunu anlama becerisinin, eleştirel düşünme bağlamında incelenmesi ve öğretilmesidir. Diğer bir anlatımla, öğrencilere eleştirel düşünme becerilerini geliştirecek metinler okutulmalı ve metne dayalı eleştirel düşünmeyi sağlayacak sorular sorulmalıdır. Okuma etkinlikleri ve görevleri öğrencilerin eleştirel düşünme süreçlerini harekete geçirecek biçimde tasarlanmalıdır. Öğrencilerin sinema ve tiyatroya gitmelerinin eleştirel düşünmelerinin manidar bir yordayıcısı olduğu düşünüldügünde, okullarda öğrenciler kültür sanat etkinlikleriyle buluşturulmalıdır. Evde çocuklarla birlikte kitap okumalarını sağlamak için il ve ilçe milli eğitim müdürlüklerinde ebeveynlere yönelik eğitimler gerçekleştirilebilir. Öğrencilerin evlerinde kendilerine ait kitap sayısını arttırılması önemlidir; bu kapsamda okullarda düşük ücretli kitap satışlarının gerçekleştirilmesi önerilebilir. Öğrencilerin kitap seçimlerinde onlara yol gösterilmelidir. Yanlı iletiler içeren, kalıp yargılarla düşünmeyi özendiren kitaplar eleştirel düşünmenin önünde bir engel oluşturacaktır. Öğrencilerin ilgilerini ve meraklarını uyandıracak, onlarda okuma zevki ve kültürü geliştirecek, okuduğunu anlama ve eleştirel düşünme becerilerini zenginleştirecek nitelikte kitaplar tercih etmeleri sağlanmalıdır.

Araştırmanın kapsamına dahil edilen değişkenlerden farklı olarak öğrencilerin eleştirel düşünme becerilerini yordaması beklenen farklı değişkenler belirlenerek araştırmalar yapılabilir. $\mathrm{Bu}$ araştırmada, eleştirel düşünme becerilerinin okuduğunu anlama, öğrenci, aile ve ev özellikleri değişkenleri ile ilişkisi incelenmiştir. Alanyazında ilişkili olduğu ifade edilen ancak bu araştırmada ele alınmayan öğrencilerin sınıf düzeyi ve akademik başarısı değişkenleri de eleştirel düşünme becerilerini yordaması beklenen değişkenler arasına eklenebilir. Bu araştırmanın çalışma grubu, ortaokul 7. sınıf düzeyinde öğrenim gören öğrencilerden oluşmaktadır. Benzer bir amaç doğrultusunda araştırmanın çalışma grubunu ilkokul ya da lise öğrencileri oluşturulabilir. Bu öğrenciler üzerinde yürütülecek araştırmaların alanyazına katkı sağlayacağı düşünülmektedir. Bu araştırma yordayıcı korelasyon türünde olup, öğrencilerin eleştirel düşünme becerilerini yordayan faktörler belirlenmiştir. Eleştirel düşünme becerilerini etkileyen faktörler dikkate alınarak deneysel desende bir araştırma yapılabilir.

\section{KAYNAKÇA}

Afflerbach, P., Cho, B., \& Kim, J. (2015). Conceptualizing and assessing higher-order thinking in reading. Theory Into Practice, 54(3), 203-212. http://dx.doi.org/10.1080/00405841.2015.1044367 
Akar, C. ve Kara, M. (2016). İlkokul 4. sınıf öğrencilerinin eleştirel düşünme becerilerinin bazı değişkenlere göre değerlendirilmesi. Uluslararası Türkçe Edebiyat Kültür Eğitim Dergisi, 5(3), 1339-1355. https://dergipark.org.tr/tr/pub/teke/issue/25000/263928

Aloqaili, A. S. (2012). The relationship between reading comprehension and critical thinking: A theoretical study. Journal of King Saud University - Languages and Translation, 24(1), 35-41. https://doi.org/10.1016/j.jksult.2011.01.001

Bağc1, H. ve Şahbaz, N. (2012). Türkçe öğretmeni adaylarının eleştirel düşünme becerileri üzerine bir değerlendirme. Mersin Üniversitesi Eğitim Fakültesi Dergisi, 8(1), 1-12. https://dergipark.org.tr/tr/pub/mersinefd/issue/17379/181479

Balta, E. E. ve Demirel, Ş. (2012). Waldmann modelinin 8. sınıf öğrencilerinin okuduğunu anlama ve eleştirel düşünme becerilerine etkisi. Turkish Studies-International Periodical For The Languages, Literature and History of Turkish or Turkic, 7(3), 469-479. http://dx.doi.org/10.7827/TurkishStudies.3627

Black, S. (2005). Teaching students to think critically. Education Digest, 70(6), 42-47. https://eric.ed.gov/?id=EJ741259

Bloom, B. S. (1995). İnsan nitelikleri ve okulda öğrenme. (Çev. Durmuş Ali Özçelik). Pegem Akademi.

Brookfield, S. D. (2012). Teaching for critical thinking: Tools and techniques to help students question their assumptions. Jossey-Bass.

Brookhart, S. M. (2010). Assess higher-order thinking skills in your classroom. ASCD.

Büyüköztürk, Ş., Çakmak, E., Akgün, Ö. E., Karadeniz, Ş. ve Demirel, F. (2013). Bilimsel araştırma yöntemleri. Pegem Akademi.

Cohen, M. (1993). Making critical thinking a classroom reality. Political Science and Politics, 26(2), 241244. https://doi.org/10.2307/419838

Cottrell, S. (2005). Critical thinking skills: Developing effective analysis and argument. Palcrave Macmillan.

Crews-Anderson, \& Timothy, A. (2007). Critical thinking. Humanities-Ebooks.

Cüceloğlu, D. (2001). L̇yi düşün doğru karar ver. Sistem Yayıncılık.

Çalık, T. ve Sezgin, F. (2005). Küreselleşme, bilgi toplumu ve eğitim. Kastamonu Eğitim Dergisi, 13(1), 5566. https://dergipark.org.tr/tr/download/article-file/509194

Demir, R. ve Aybek, B. (2014). Lise öğrencilerinin eleştirel düşünme eğilimlerinin çeşitli değişkenler açısından incelenmesi. Muğla Sitkı Koçman Üniversitesi Sosyal Bilimler Enstitüsü Dergisi, 32(2), 122-140. https://dergipark.org.tr/tr/download/article-file/217205

Demirel, Ö. (2002). Türkçe öğretimi. Pegem Akademi.

Doğan, N. (2013). Eleştirel düşünmenin ölçülmesi. Cito Eğitim: Kuram ve Uygulama, 22, 29-42. https://app.trdizin.gov.tr/makale/TVRVek5qSTJOZz09/elestirel-dusunmenin-olculmesi

Eales-Reynolds, L. J., Brenda, J., Jones, P., \& McCreery, E. (2013). Critical thinking skills for education students. Learning Matters.

Forshaw, M. (2012). Critical thinking for psychology. British Psychological Society and John Wiley and Sons Ltd. 
Fraenkel, R. M., \& Wallen, N. E. (2006). How to design and evaluate research in education. McGraw-Hill International Edition.

Field, A. (2013). Discovering statistics using IBM SPSS statistics. SAGE Publications Inc.

Gelder, T. V. (2005). Teaching critical learning: Some lessons from cognitive science. College Teaching, 45(1), 1-6. https://sites.google.com/site/timvangelder/publications-1/teaching-critical-thinking

Ghabanchi, Z., \& Behrooznia, S. (2014). The impact of brainstroming on reading comprehension and critical thinking ability of EEL learners. Procedia Social and Behavioral Sciences, 98(2014), 513-521. https://doi:10.1016/j.sbspro.2014.03.447

Gök, B. ve Erdoğan, T. (2011). Sınıf öğretmeni adaylarının yaratıcı düşünme düzeyleri ve eleştirel düşünme eğilimlerinin incelenmesi. Ankara Üniversitesi Eğitim Bilimleri Fakültesi Dergisi, 44(2), 29-51. https://doi.org/10.1501/Egifak_0000001223

Hooks, B. (2010). Teaching critical thinking: Practical wisdom. Routledge.

Jones, B. F. (1985) Reading and thinking. A. Costa (Ed.) Developing minds: A resource book for teaching thinking. (p. 108-114). Association for Supervision and Curriculum Development.

Kaloç, R. (2005). Orta öğretim kurumu öğrencilerinin eleştirel düşünme ve eleştirel düşünme becerilerini etkileyen etmenler (Tez Numarası: 206255). [Yüksek lisans tezi, Gazi Üniversitesi]. Yükseköğretim Kurulu Ulusal Tez Merkezi.

Karadüz, A. (2010) Dil becerileri ve eleştirel düşünme. Turkish Studies, 5(3), 1566-1593. http://dx.doi.org/10.7827/TurkishStudies.1572

Karakaş, A. S., Altun, Ö. Ş., Ekinci, M., Olçun, Z. ve Taşkın, M. (2016). Hemşirelik öğrencilerinin eleştirel düşünme düzeyleri ve kitap okuma alışkanlıkları arasındaki ilişki. Anadolu Hemşirelik ve Sağllk Bilimleri Dergisi, 19(2), 116-121. https://doi.org/10.17049/ahsbd.66789

Karasar, N. (2012). Bilimsel araştırma yöntemi. Nobel Yayınları.

Karimi, L., \& Veisi, F. (2016). The impact of teaching critical thinking skills on reading comprehension of Iranian intermediate EFL learners. Theory and Practice in Language Studies, 6(9), 1869-1876. http://doi.org/10.17507/tpls.0609.21

Koç, C. (2007). Aktif öğrenmenin okuduğunu anlama eleştirel düşünme ve sınıf içi etkileşim üzerindeki etkileri (Tez Numarası: 215781). [Doktora tezi, Dokuz Eylül Üniversitesi]. İzmir.

Kurnaz-Adıbatmaz, F. B. ve Kutlu, Ö. (2020). Bilimsel düşünme becerilerinin ölçülmesi. Pegem Akademi.

Kutlu, Ö. (1999). İlköğretim okullarındaki Türkçe ders kitaplarındaki okuma parçalarına dayalı olarak hazırlanmış sorular üzerine bir inceleme. Eğitim ve Bilim Dergisi, 23(111), 14-21. http://egitimvebilim.ted.org.tr/index.php/EB/article/view/5340

Kutlu, Ö. ve Erman Aslanoğlu, A. (2008). Dinlediğini anlama becerisinin ölçülmesi. VII. Ulusal Sinıf Öğretmenliği Ĕ̆itimi Sempozyumu, 2-4 Mayıs, Çanakkale Onsekiz Mart Üniversitesi.

Kutlu, Ö., Yıldırım, Ö., Bilican, S. ve Kumandaş, H. (2011). İlköğretim 5. sınıf öğrencilerinin okuduğunu anlamada başarılı olup-olmama durumlarının kestirilmesinde etkili olan değişkenlerin incelenmesi. Eğitimde ve Psikolojide Ölçme ve Değerlendirme Dergisi, 2(1), 132-139. https://dergipark.org.tr/tr/pub/epod/issue/5806/77235 
Kutlu, Ö., Doğan, C. D. ve Karakaya, İ. (2017). Ölçme ve değerlendirme: Performansa ve portfolyoya dayalı durum belirleme (5. Bask1). Pegem Akademi.

Kutlu, Ö. ve Altıntaş, Ö. (2021). Psikolojik ölçmelerin kısa tarihi ve 21. yüzyılda sınıf içi durum belirleme anlayışı. Trakya Eğitim Dergisi, 11(3), 1599-1620. http://doi.org/10.24315/tred.896121

Küçükali, R. ve Akbaş, H. (2015). Eleştirel düşüncenin bilimlerin gelişmesine katkıları [The Contributions of Critical Thinking to the Developments of the Science Fields]. Atatürk Üniversitesi Sosyal Bilimler Enstitüsü Dergisi, 19(3), 1-10. https://dergipark.org.tr/tr/pub/ataunisosbil/issue/45086/563141

Leader, L. F., \& Middleton, J. A. (2004). Promoting critical-thinking dispositions by using problem solving in middle school mathematics. RMLE Online, 28(1), 55-71. https://files.eric.ed.gov/fulltext/EJ807418.pdf

Marzban, A., \& Barati, Z. (2016). On the relationship between critical thinking ability, language learning strategies, and reading comprehension of male and female intermediate EFL university students. Theory and Practice in Language Studies, 6(6), 1241-1247. http://doi.org/10.17507/tpls.0606.14

MEB (2006). İlköğretim Türkçe dersi öğretim programı ve kılavuzu (6-8. sinıflar). http://ttkb.meb.gov.tr/program2.aspx adresinden 22.06.2016 tarihinde alınmıştır.

MEB (2009). İlköğretim Türkçe dersi öğretim programı ve kılavuzu (1-5. sinıflar). http://ttkb.meb.gov.tr/program2.aspx adresinden 22.06.2016 tarihinde alınmıştır.

MEB (2011). MEB 21. yüzyll öğrenci profili. Milli Eğitim Bakanlığı Basımevi.

MEB (2015). PISA 2012 araştırması ulusal nihai rapor. Milli Eğitim Bakanlığı Basımevi.

MEB (2016). PISA 2015 ulusal raporu. Milli Eğitim Bakanlığı Basımevi.

MEB (2019). PISA 2018 Türkiye ön raporu. Milli Eğitim Bakanlığı Basımevi.

Moon, J. (2007). Critical Thinking: An exploration of theory and practice. Routledge.

Özdemir, H. F. (2006). Kaliforniya Zihinsel Güdülenme Ölçeği’nin uyarlanması (Tez Numarası: 625910). [Yüksek lisans tezi, Ankara Üniversitesi]. Ankara.

Özdemir, E. (2011). Eleştirel okuma. Bilgi Yayınevi.

Öztürk, N. (2006). Hemşirelik öğrencilerinin eleştirel düşünme düzeyleri ve eleştirel düşünmeyi etkileyen faktörler (Tez Numarası: 196306). [Yüksek lisans tezi, Cumhuriyet Üniversitesi]. Sivas.

Pallant, J. (2015). SPSS kullanma kılavuzu: SPSS ile adım adım veri analizi (S. Balcı ve B. Ahi, Çev. Ed.). Anı Yayınc1lık (2002).

Piji Küçük, D. ve Uzun Y. B. (2013). Müzik öğretmeni adaylarının eleştirel düşünme eğilimleri. Ahi Evran Üniversitesi Kirşehir Eğitim Fakültesi Dergisi, 14(1), 327-345. https://kefad2.ahievran.edu.tr/archieve/pdfler/Cilt14Sayi1/JKEF_14_1_2013_327-345.pdf

Rirozzi, R., Starrks-Martin, G., \& Dziewisz, J. B. (2008). Critical reading, critical thinking. Pearson Prentice Hall.

Seferoğlu, S. S. ve Akbıyık, C. (2006). Eleştirel düşünme ve öğretimi. Hacettepe Üniversitesi Eğitim $\begin{array}{llll}\text { Bilimleri Fakültesi } & \text { Dergisi, } & \text { 30(30), }\end{array}$ https://dergipark.org.tr/tr/pub/hunefd/issue/7806/102380 
Susar Kırmızı, F., Fenli, A. ve Kasap, D. (2014). Sınıf öğretmeni adaylarının eleştirel düşünme eğilimleri ile okuma alışkanlıklarına yönelik tutumları arasındaki ilişki. Uluslararası Türkçe Edebiyat Kültür Eğitim Dergisi, 3(1), 354-367. https://dergipark.org.tr/tr/download/article-file/136910

Şaban, A. (2002). Öğrenme ögretme süreci: Yeni teori ve yaklaşımlar. Nobel Yayıncılık.

Şahinel, S. (2002). Eleştirel düşünme. Pegem Akademi.

Şentürk, Ü. (2008). Enformasyon toplumunda eğitimin yeri. Türk Ĕgitim Bilimleri Dergisi, 6(3), 487-506. https://dergipark.org.tr/tr/pub/tebd/issue/26111/275102

Şirin, S. (2015). Yol ayrımındaki Türkiye. Doğan Yayıncılık.

Tabachnick, B. G., \& Fidell, L. S. (2001). Using multivariate statistics (4 $4^{\text {th }}$ Edition). A Pearson Education Company.

Yousefi, S., \& Mohammadi, M. (2016). Critical thinking and reading comprehension among postgraduate students: The case of gender and language proficiency level. Journal of Language Teaching and Research, 7(4), 802-807. http://dx.doi.org10.17507/j1tr.0704.23 